\title{
Hubungan antara Besar Defek, Massa dan Fungsi Ventrikel Kiri dengan N-Terminal Pro Brain Natriuretic Peptide pada Anak dengan Defek Septum Ventrikel
}

\author{
Aldy Rinaldi, Erling David Kaunang, Helena Anneke Sendow Tangkilisan \\ Departemen Ilmu Kesehatan Anak Fakultas Kedokteran Universitas Sam Ratulangi/ RS Prof Dr. R. D. Kandou, Manado
}

\begin{abstract}
Latar belakang. Defek septum ventrikel (DSV) adalah salah satu bentuk penyakit jantung bawaan (PJB) yang paling sering ditemukan. $N$-Terminal Pro Brain Natriuretic Peptide (NT-proBNP) telah terbukti efektif sebagai penanda fungsi jantung pada penyakit jantung didapat, namun peran NT-proBNP sebagai penunjang diagnosis dan tindakan klinis pada pasien PJB, terutama DSV masih belum jelas Tujuan. Menganalisis hubungan antara besarnya defek, massa dan fungsi ventrikel kiri dengan kadar NT-proBNP pada pasien anak dengan DSV.

Metode. Penelitian dilakukan di RSUP Prof. Dr. R.D. Kandou, Manado pada bulan September sampai Desember 2015. Subyek adalah anak berumur 6 bulan sampai 6 tahun dengan DSV yang memenuhi kriteria inklusi. Kami menggunakan jenis penelitian observasional analitik bentuk korelatif dengan pendekatan potong lintang. Analisis korelasi menggunakan uji Pearson dan regresi linier sederhana. Secara statistik signifikan bila $\mathrm{p}<0,05$.

Hasil. Terdapat hubungan positif antara besar defek $(r=0,772, p<0,001)$ dan massa ventrikel kiri $(M V K)(r=0,476, p<0,001)$ dengan kadar NT-proBNP pada anak dengan DSV. Terdapat hubungan negatif antara fraksi ejeksi $(\mathrm{FE})(\mathrm{r}=-0,699 \mathrm{p}<0,001)$ dengan kadar NT-proBNP pada anak DSV.

Kesimpulan. Terdapat hubungan antara besar defek, MVK dan FE pada anak dengan DSV. Dapat dipertimbangkan pemeriksaan NT-proBNP pada anak dengan DSV untuk deteksi dini terjadinya komplikasi. Sari Pediatri 2016;17(6):413-7.
\end{abstract}

Kata kunci: NT-proBNP, DSV, anak, besar defek, MVK, fraksi ejeksi

\section{Correlation between Defect Size, Volume and Function of Right Ventricle with N-Terminal Pro Brain Natriuretic Peptide in Children With Ventricle Septal Defect}

\author{
Aldy Rinaldi, Erling David Kaunang, Helena Anneke Sendow Tangkilisan
}

Background. Ventricle septal defect (VSD) is the most common congenital heart defect (CHD). N-Terminal Pro Brain Natriuretic Peptide (NT-proBNP) is a cardiac marker for acquired cardiac diseases, but the role of NT-proBNP in CHD especialy in VSD still unclear.

Objectives. To analyze the correlation between defect size, left ventricle mass (LVM) and ejection fraction (EF) with NT-proBNP level in children with VSD.

Methods. This study was done in Prof. Dr. R.D. Kandou Hospital, Manado, North Sulawesi, Indonesia from September 2015 until December 2015. Subjects were children with VSD age 6 months until 6 years. We conducted correlation observational analysisitic with cross-sectional approach in this study. Correlation analysis with simple linear regression and Pearson test. It was considered statistically significant if $\mathrm{p}<0,05$.

Results. We found positive correlation between defect size $(r=0,772, p<0,001)$, and LVM $(r=0,476, p<0,001)$ with NT-proBNP level in children with VSD. Negative correlation was found between EF ( $\mathrm{r}=-0,699, \mathrm{p}<0,001)$ with NT-proBNP level in children with VSD. Conclusions. In our study, we found correlation between defect size, LVM and EF with NT-proBNP level in children with VSD. We conclude that NT-proBNP test can be considered for early detection of VSD complication. Sari Pediatr 2016;17(6):413-7.

Keywords: VSD, NT-proBNP, defect size, LVM, EF

\footnotetext{
Alamat korespondensi: Dr. Aldy Rinaldi. Departemen Ilmu Kesehatan Anak Fakultas Kedokteran Universitas Sam Ratulangi Rumah Sakit Prof Dr. R. D. Kandou. Jl Raya Tanawangko, Manado. Tel. +62 (431) 821652. Fax. +62 (431) 859091. E-mail: aldy-84@hotmail.com
} 
Aldy Rinaldi dkk: Hubungan antara besar defek, massa dan fungsi ventrikel kiri dengan NT-proBNP pada DSV

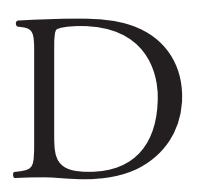

efek septum ventrikel (DSV) adalah salah satu bentuk penyakit jantung bawaan (PJB) yang paling sering ditemukan. Prevalensi DSV ini berkisar 1,6 sampai 2,6 per 1000 kelahiran hidup, kurang lebih mencapai $40 \%$ dari semua kelainan jantung bawaan. ${ }^{1}$

Sejak tahun 1950-an telah ada laporan hubungan humoral antara jantung dan ginjal di mana dilatasi atrium kanan jantung menimbulkan natriuresis dan diuresis. Sudoh $\mathrm{dkk}^{2}$ pada tahun 1988 mendapatkan Brain natriuretic peptide (BNP) dari otak babi yang ditemukan pula pada miosit ventrikel jantung.

Brain natriuretic peptide dan prekursor inaktifnya berupa $N$-terminal pro-brain natriuretic peptide (NTproBNP) merupakan hormon yang dilepaskan ke dalam sirkulasi sewaktu terjadi after pressure overload, ekspansi volume jantung dan meningkatnya stress dinding miokardium. ${ }^{3}$ Bentuk aktif dari $B N P$ ini mempunyai efek natriuretic, vasodilatasi dan diuresis. Hormon ini telah terbukti kemampuannya untuk deteksi gangguan jantung pada pasien dengan gagal jantung. ${ }^{4}$

Meskipun NT-proBNP telah terbukti efektif sebagai marker pada penyakit jantung didapat, peran mereka sebagai penunjang diagnosis dan tindakan klinis pada pasien PJB, terutama DSV masih belum jelas. Penyebab utama kematian pada defek septum ventrikel adalah gagal jantung kronik dan hipertensi pulmonal ireversibel. Diagnosis pasti dari DSV ini adalah dengan menggunakan ekokardiografi. Dokter anak konsultan jantung anak sampai saat ini masih terbatas, sehingga pemeriksaan ekokardiografi ini belum rutin dilakukan. Diharapkan pemeriksaan NT-proBNP ini dapat menunjang pemeriksaan ekokardiografi untuk deteksi dini terjadinya komplikasi pada anak dengan DSV.

\section{Metode}

Penelitian observasional analitik korelatif yang dilakukan dengan pendekatan potong lintang (cross sectional). Penelitian dilakukan di RSUP Prof. Dr. R.D. Kandou, Manado pada bulan September 2015 sampai Desember 2015. Subjek penelitian adalah anak usia 6 bulan - 6 tahun dengan DSV yang terdiagnosis menggunakan ekokardiografi. Subjek dengan penyakit penyerta seperti penyakit susunan saraf pusat, sindroma neftrotik, glumerulonefritis akut, penyakit paru kronik, sindrom Eisenmenger di eksklusi dalam penelitian ini. Jumlah subjek dalam penelitian ini 38 anak yang datang ke RS untuk kontrol DSV dan dilakukan ekokardiografi untuk menilai besar defek, massa ventrikel kiri (MVK) dan fraksi ejeksi (FE). Setelah persetujuan informed consent, dilakukan anamnesis dan pemeriksaan fisik untuk menyingkirkan faktor perancu, dan pemeriksaan NT-proBNP. Penelitian dilaksanakan di bawah persetujuan komite etik penelitian RSUP Prof. Dr. R.D. Kandou, Manado.

Data yang dikumpulkan adalah jenis kelamin, usia, BB, TB, besar defek DSV, MVK dan FE. Analisa data deskriptif digunakan untuk menganalisis karakteristik anak dan dilaporkan dalam bentuk tabel distributif. Data parametrik dinyatakan dalam rerata, simpangan baku (SB) dan indeks kepercayaan (IK) 95\%. Analisis korelasi antara kadar NT-proBNP dengan besar defek DSV, massa dan fungsi ventrikel kiri menggunakan uji Pearson dan regresi linier sederhana. Secara statistik signifikan bila nilai $\mathrm{p}<0,05$. Digunakan SPSS versi 22 untuk analisis data.

\section{Hasil}

Didapatkan 38 subjek masuk dalam kriteria inklusi. Distribusi berdasarkan jenis kelamin, 20 laki-laki dan 18 perempuan. Distribusi berdasarkan usia, BB, TB, besar defek, FE, MVK, dan NT-proBNP tertera pada Tabel 1.

Berdasarkan hasil analisis korelasi Pearson, hubungan besar defek DSV dengan NT-proBNP, didapatkan $r=0,772(p<0,001)$. Hasil menunjukkan terdapat hubungan positif bermakna kuat antara besar defek dengan NT-proBNP. Untuk grafik scatterplot hubungan besar defek DSV dengan NTproBNP tertera pada Gambar 1. Hubungan MVK dengan NT-proBNP didapatkan $\mathrm{r}=0,476(\mathrm{p}<0,001)$. Hasil menunjukkan terdapat hubungan positif bermakna sedang antara MVK dengan NT-proBNP. Untuk grafik Scatterplot hubungan MVK dengan NT-proBNP tertera pada Gambar 2. Hubungan FE dengan NT-proBNP, didapatkan $r=-0,699$ $(\mathrm{p}<0,001)$. Hasil menunjukkan terdapat hubungan negatif bermakna kuat antara FE dengan NTproBNP. Grafik scatterplot tertera pada Gambar 3. 
Aldy Rinaldi dkk: Hubungan antara besar defek, massa dan fungsi ventrikel kiri dengan NT-proBNP pada DSV

Tabel 1. Distribusi usia, berat badan, tinggi badan, dan IMT

\begin{tabular}{lccc}
\hline Variabel & Rerata & SB & IK95\% \\
\hline Usia & 31,58 & 21,509 & $24,51-38,65$ \\
BB $(\mathrm{kg})$ & 13,54 & 5,950 & $11,59-15,50$ \\
TB $(\mathrm{cm})$ & 86,21 & 16,361 & $80,83-91,59$ \\
Besar defek $(\mathrm{mm})$ & 5,529 & 3,0023 & $4,542-6,516$ \\
FE $(\%)$ & 61.424 & 17,228 & $55,76-67,09$ \\
MVK $\left(\mathrm{gr} / \mathrm{m}^{2}\right)$ & 111,95 & 45,054 & $97,14-126.76$ \\
NT-proBNP $(\mathrm{pg} / \mathrm{ml})$ & 242,8684 & 238,18596 & $164.5786-321,1582$ \\
\hline
\end{tabular}

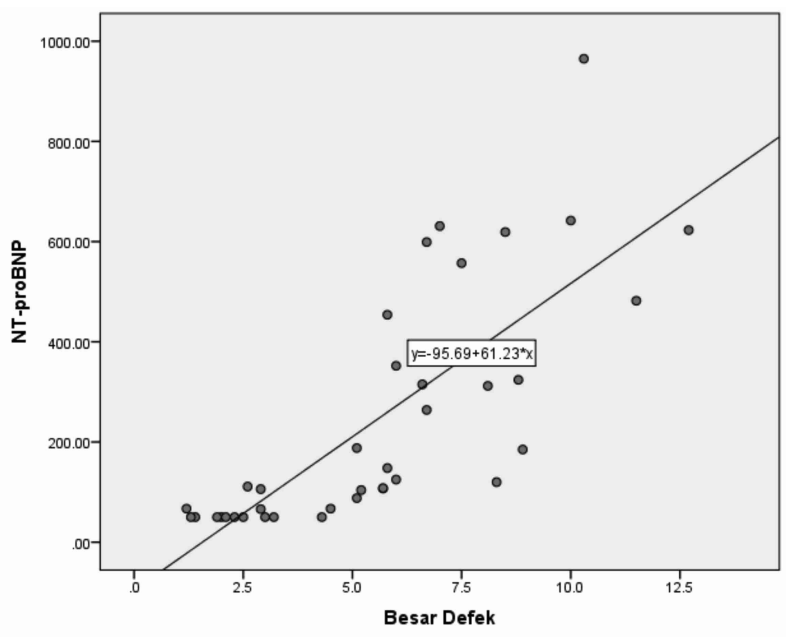

Gambar 1. Scatterplot hubungan besar defek DSV dengan NT-proBNP.

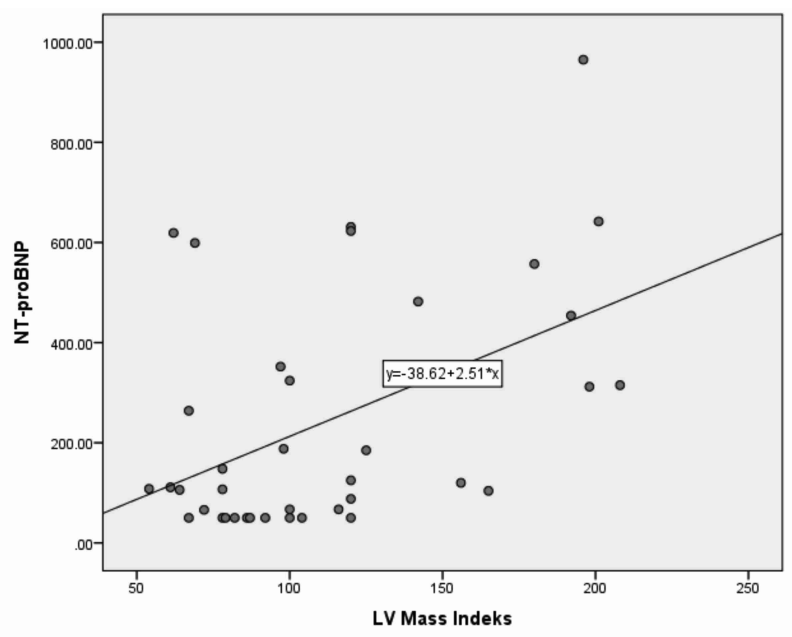

Gambar 2. Scatterplot hubungan MVK dengan NT-proBNP.

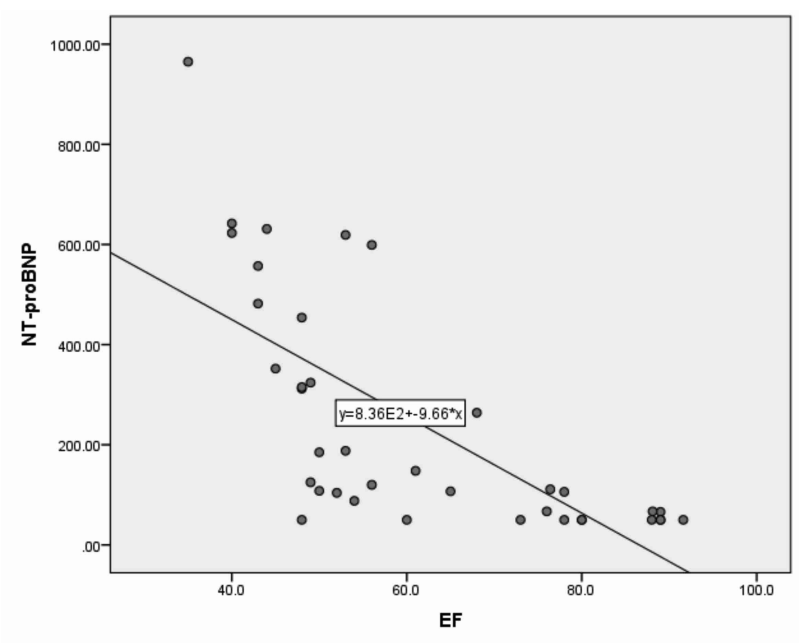

Gambar 3. Scatterplot hubungan FE dengan NT-proBNP.

\section{Pembahasan}

Kami memilih anak berumur 6 bulan sampai 6 tahun dengan alasan bahwa kadar NT-proBNP tinggi setelah lahir dan akan menurun secara bertahap dengan bertambahnya umur. ${ }^{5,6}$ Hingga saat ini, belum ada batasan resmi kadar NT-proBNP pada anak. Nir $\mathrm{dkk}^{5}$ melakukan pemeriksaan NT-proBNP pada 690 anak dengan rentang umur 0 hari sampai 18 tahun. Peneliti menyimpulkan bahwa kadar NT-pro $B N P$ ini sangat tinggi setelah lahir dan menurun secara drastis setelah umur 1 hari. Kadar NT-proBNP tersebut menurun secara bertahap selaras dengan pertambahan umur. Penurunan secara signifikan didapatkan antara umur 1 bulan dan 18 tahun.

Kami mendapatkan hubungan positif antara besar defek DSV dengan kadar NT-proBNP. Penelitian 
Aldy Rinaldi dkk: Hubungan antara besar defek, massa dan fungsi ventrikel kiri dengan NT-proBNP pada DSV

kami mendukung penelitian dari Koch $\mathrm{dkk}^{7}$ dan Jannet $\mathrm{dkk}^{8}$ yang menyimpulkan bahwa keparahan pirau kiri ke kanan berhubungan positif dengan NT-proBNP.

Penelitian kami juga memperlihatkan hubungan positif antara MVK dengan kadar NT-proBNP pada anak dengan DSV. Secara patofisiologi, anak dengan DSV dapat terjadi peningkatan MVK sehingga menyebabkan gangguan hemodinamik. Hasil penelitian kami mendukung penelitian sebelumnya yang melaporkan hasil pemeriksaan NT-proBNP pada pasien high risk acute lymphoblastic leukemia $(A L L H R)$ setelah terapi doksorubisin. Hasil penelitian mereka didapatkan hubungan antara peningkatan kadar NT-proBNP dengan peningkatan MVK. ${ }^{9}$

Salah satu komplikasi yang dapat terjadi pada DSV adalah gagal jantung. Untuk mengetahui adanya gagal jantung pada anak digunakan penilaian dengan skor Ross dan pemeriksaan ekokardiografi untuk menilai FE. Pemeriksaan NT-proBNP sudah digunakan untuk menilai gagal jantung dan keberhasilan pengobatannya pada populasi dewasa. Penelitian kami mendukung penelitian sebelumnya yang melaporkan bahwa NT-proBNP ini berhubungan dengan fungsi ventrikel pada anak dengan PJB. ${ }^{7}$ Penelitian dari Wu dkk ${ }^{10}$ melaporkan bahwa NT-proBNP dapat dipertimbangkan sebagai alat diagnostik gagal jantung pada anak dengan DSV. Plasma NT-proBNP berhubungan secara positif dengan skor Ross. Sahin $\mathrm{dkk}^{11}$ melaporkan bahwa kadar NT-proBNP yang meningkat berhubungan secara kuat dengan keparahan gagal jantung sehingga dapat digunakan sebagai skrining pasien PJB dengan risiko gagal jantung. Berdasarkan penelitian yang kami lakukan, semakin menurun FE maka didapatkan kadar NT-proBNP meningkat secara bermakna sehingga pemeriksaan NT-proBNP dapat dipertimbangkan untuk melihat fungsi jantung pada anak dengan DSV.

Kelemahan pada penelitian kami tidak dilakukan analisis multivariat untuk membandingkan masingmasing variabel. Kami juga tidak menilai skor gagal jantung pada sampel. Berdasarkan hal tersebut, perlu dilakukan penelitian lanjutan dengan desain kohort prospektif pada anak DSV untuk menilai peningkatan kadar NT-proBNP secara berkala untuk melihat hubungannya dengan besar defek, MVK, dan pada anak dengan DSV.

\section{Kesimpulan}

Terdapat hubungan positif antara besar defek, MVK dan hubungan negatif FE dengan nilai NT-proBNP pada anak dengan defek septum ventrikel. Dapat dipertimbangkan pemeriksaan NT-proBNP untuk melihat kondisi dari besar defek, MVK dan FE pada anak dengan DSV selain pemeriksaan ekokardiografi.

\section{Daftar pustaka}

1. Hoffman JIE, Kaplan S. The incidence of congenital heart disease. J Am Coll Cardiol 2002;39:1890-900.

2. Sudoh T, Kangawa K, Minamino N, Matsuo H. A new natriuretic peptide in porcine brain. Nature. 1988;332:78-81.

3. Levin ER, Gardner DG, Samson WK. Natriuretic peptides. N Engl J Med 2008; 339:321-8.

4. Jessup M, Abraham WT, Casey DE. Focused update: ACCF/AHA guidelines for the diagnosis and management of heart failure in adults: a report of the American College of Cardiology Foundation/American Heart Association Task Force on Practice Guidelines: developed in collaboration with the International Society for Heart and Lung Transplantation. Circulation 2009;119:19772016.

5. Nir A, Bar-Oz B, Perles Z. N-terminal pro-B-type natriuretic peptide: reference plasma levels from birth to adolescence: Elevated levels at birth and in heart diseases. Acta Paediatr 2004;93:603-7.

6. Mir TS, Gardner DG, Samson WK. Plasma concentrations of aminoterminal pro brain natriuretic peptide in neonates. Pediatrics 2007;123:600-9.

7. Koch A, Singer H. Normal values of B-type natriuretic peptide in infants, children, and adolescents. Heart 2003;89:875-8.

8. Jannet A, Annemien E, Bosch V, Boersma E, Jolien W. The usefulness of brain natriuretic peptide in simple congenital heart disease - a systematic review. Cardiology in the Young 2012;10:1-10.

9. Steven E, Miller T, Scully E, Lipsitz S, Rifai N, Silverman, L, et al. Changes in cardiac biomarkers during doxorubicin treatment of pediatric patients with highrisk acute lymphoblastic leukemia: associations with long-term echocardiographic outcomes. J Clin Oncol 2012;30:1042-9.

10. Wu YR, Chen SB, Huang MR, Zhang YQ, Sun K, Chen $S$. Diagnostic value of plasma concentration of pro-brain 
Aldy Rinaldi dkk: Hubungan antara besar defek, massa dan fungsi ventrikel kiri dengan NT-proBNP pada DSV

natriuretic peptide in congestive heart failure in pediatric patients with ventricular septal defects. Chinese Pediatr 2005;43;161-4.

11. Sahin M, Portakal O, Karagoz T, Hascelik G, Ozkutlu
S. Diagnostic performance of BNP and NT-proBNP measurements in children with heart failure based on congenital heart defects and cardiomyopathies. Clin Biochem 2010;43:1278-81. 